\title{
The Roles of GRASP55/65 in Golgi Formation and Function ゴルジ体の構造と機能におけるGRASP55/65の役割
}

\author{
Key Words: glycosylation, Golgi apparatus, Golgi stack
}

The Golgi apparatus is an organelle present in almost all eukaryotic cells. In general, the Golgi comprises a unique multilayered structure called the Golgi stack, which contains several flattened, vertically overlaid, cisternae. The number of cisternae found in a Golgi stack varies among biological species. Golgi stacks are typically composed of three compartments: the cis-cisternae, which receive vesicles from the endoplasmic reticulum (ER); the transcisternae, which release vesicles to other cellular compartments such as endosomes; and medial-cisternae, which lie between the cis- and trans-cisternae. The outermost parts of the Golgi comprise complex tubular and vesicular structures called the cis- and transGolgi networks, which function as the entrance and exit for the Golgi stack, respectively. In these compartments, enzymes responsible for post-translational protein modification (in processes such as glycosylation) are localized to specific cisternae and perform their function in an ordered fashion as proteins pass through the Golgi stack. In mammals, several Golgi stacks are horizontally connected by tubular structures and thus form a ribbon-like entity called the Golgi ribbon, which is most often localized around the nucleus.

The main functions of the Golgi bodies include post-translational modification and sorting of proteins. Among the proteins synthesized in the cytoplasm, those with an ER-targeting signal (either an ER signal sequence or a transmembrane domain) are translocated into the ER. Subsequently, COPII vesicles transport these proteins to the cis-Golgi network, through which they enter the Golgi apparatus. They pass through the Golgi stack by means of vesicular transport and/or cisternal maturation and, at the transGolgi network, exit the Golgi for transportation towards their next destination, which may include the cell surface, endosomes, and lysosomes. As they pass through the Golgi, most proteins are glycosylated. At least two types of sugar chains may be attached to the proteins: $O$-linked sugar chains, which are added to the hydroxyl groups of serine and threonine residues; and $N$-linked sugar chains, added to the amino groups of asparagine residues. $N$-glycosylation begins in the ER, wherein the preformed precursor structure $\mathrm{Glc}_{3} \mathrm{Man}_{9} \mathrm{GlcNAc}_{2}$ is attached, and continues in the Golgi where further modification takes place. The process of $O$-glycosylation occurs exclusively in the Golgi, wherein sugar residues are attached in succession via elongation reactions. These reactions take place sequentially, with cargo proteins being modified by enzymes
ゴルジ体はほぼすべての真核細胞に存在する細胞内小器 官の1つである。扁平な囊が数枚、縦方向に積み重なった、 層板と呼ばれる構造をとる（囊の枚数は生物によって異な る)。層板は、小胞体からゴルジ体へ運ばれてくる小胞を受 け入れる面であるシス、小胞を輸送経路の先へと放出するト ランス、そしてシスとトランスに挟まれて存在する中間部、 の3つの異なるコンパートメントに分かれている。ゴルジ体 の最も外側に位置する、小胞・管状の複雑な構造は、シスゴ ルジネットワーク、トランスゴルジネットワークと呼ばれ、 それぞれ、ゴルジ体への入り口、出口として機能する。これ らのコンパートメントでは、様々な翻訳後修飾に関わる酵 素、例えば糖鎖修飾酵素がそれぞれのコンパートメント内の 特異的な部位に局在するため、役割が部位により異なる。ほ 乳類の層板は管状の構造を介して横方向に連結し、ほとんど の場合、核の周囲にリボン状のゴルジリボンと呼ばれる構造 を形成する。

ゴルジ体は、タンパク質の翻訳後修飾と分類において重 要な役割を果たす。細胞質で生合成されたタンパク質のう ち、小胞体移行シグナル配列や膜貫通部位を持つものは、小 胞体へ移動する。ついで、COPII と呼ばれる小胞によってシ スゴルジ網に運ばれる。ゴルジ体の中に入ったタンパク質 は、小胞輸送あるいは層板成熟によって、ゴルジ体内を通過 する。これらのタンパク質は、細胞表面、エンドソームやリ ソソーム、といったそれぞれの目的地に向けて、ゴルジ体の 出口であるトランスゴルジ網から運び出される。なお、ゴル ジ層板を通過する過程で、ほとんどのタンパク質に糖鎖が付 加される。タンパク質に付加される糖鎖には、アスパラギ ン残基のアミノ基に結合する $N$-結合型と、セリン・トレオ ニン残基の水酸基に結合する $O$-結合型などいくつかの種類 がある。 $N$-結合型糖鎖は、まず小胞体で糖鎖前駆体である $\mathrm{Glc}_{3} \mathrm{Man}_{9} \mathrm{GlcNAc}_{2}$ が付加された後、一部トリミングされ、次 にゴルジ体でより複雑な修飾を受け完成する。これに対して $O$-結合型糖鎖は、小胞体ではなくゴルジ体内で、糖 1 残基ず つの伸長付加反応によって形成される。これらの一連の反応 は、まずシスゴルジに局在する酵素によって、引き続き中間、 トランスゴルジに局在する酵素によって触媒される。

Golgi reassembly and stacking protein、GRASP65、 GRASP55 と名付けられた2つのタンパク質はゴルジ層板を 形成する因子として発見された [Barr et al., GRASP65, a protein involved in the stacking of Golgi cisternae. Cell (1997) 253262]、 [Shorter et al., GRASP55, a second mammalian GRASP 
in the cis-, medial-, and trans-Golgi, in the given order.

Golgi reassembly and stacking proteins (GRASP) 65 and 55 were first discovered as factors involved in the formation of Golgi stacks [Barr et al., GRASP65, a protein involved in the stacking of Golgi cisternae, Cell (1997) 253-262], [Shorter et al., GRASP55, a second mammalian GRASP protein involved in the stacking of Golgi cisternae in a cell-free system, EMBO J. (1999) 4949-4960]. GRASP65 is localized to the cis-cisternae, while GRASP55 is localized to the medial- and trans-cisternae. Both GRASPs bind to golgins, a family of proteins present on the cytoplasmic face of the Golgi that contain coiled-coil domains and form rod-like structures. Specifically, GRASP65 binds to GM130, a golgin on the cis-Golgi, and GRASP55 binds to Golgin45 on the trans-Golgi. Evidence suggests that the contribution of GRASP55/65 to the formation of the Golgi stack structure is due to their ability to transoligomerize between cisternae and thereby link adjacent membranes. However, whether GRASPs regulate or participate in other Golgi functions, such as glycosylation and protein sorting, remains unclear.

Reviewed in this report are the following three recently published articles, which discuss the various roles of GRASP55/65 in the formation and functions of the Golgi.

1: Lee et al., Membrane adhesion dictates Golgi stacking and cisternal morphology, Proc. Natl. Acad. Sci. USA. (2014) 18491854.

2: Jarvela and Linstedt, Isoform-specific tethering links the Golgi ribbon to maintain compartmentalization, Mol. Biol. Cell (2014) 133-144.

3: Xiang et al., Regulation of protein glycosylation and sorting by the Golgi matrix protein GRASP55/65, Nat. Commun. (2013) 1659.

In article 1, Lee et al. examined the contributions of GRASP55/65, GM130, and Golgin45 to Golgi stack formation. Compared to controls, single knockdown with specific siRNAs of either GRASP55 or 65 alone increased the maximum luminal width of flattened cisternae by 1.2-fold, while the double knockdown of both together resulted in a 2.6-fold increase. In contrast to the other two studies, this study showed that both the single and double knockdowns disturbed the flattening of Golgi cisternae but did not disturb their stacking. Exogenous expression of GRASP55, GRASP65, GM130, or Golgin45 in the double knockdown cells restored the flatness of the cisternae to the level of the single knockdown; however, the level of restoration was reduced with GM130 compared to the other proteins. These results suggest that changes to the flatness of the cisternae, induced by knockdown of GRASP55/65, are reversible and that the function of GRASP55/65 and Golgin45 in Golgi stacking is complementarily. protein involved in the stacking of Golgi cisternae in a cell-free system. EMBO J. (1999）4949-4960]。GRASP65 はゴルジ 体のシス、GRASP55 は中間およびトランス囊に局在する。 GRASP65 はシス囊に局在し、golginの一つである GM130 と 結合する。一方、GRASP55 はトランス囊に局在し、golginの 一つである Golgin45 と結合する。golgin とは、ゴルジ体の細 胞質面に局在し、コイルドコイル構造を有する長い竿状の一 連のタンパク質群のことである。GRASP55/65は囊と囊の間 に存在し、それぞれがトランス型のホモ二量体を形成するこ とによって囊を近傍につなぎとめ、縦方向の層板形成に寄与 すると考えられている。

生物種による多少の違いはあるが、GRASP55/65が、ゴ ルジ体の層板形成に寄与することは明らかである。しかし、 GRASP55/65がゴルジ体の機能、つまりタンパク質の糖鎖付 加や分類をどのように制御しているかについてはまだ不明な 点が多い。本稿では、最近出版されたGRASP55/65に関係す る、下記の 3 報を紹介することにより、これらの二つのタン パク質のゴルジ体の構造と機能に果たす役割を紹介する。

1: Lee et al., Membrane adhesion dictates Golgi stacking and cisternal morphology, Proc. Natl. Acad. Sci. USA. (2014) 18491854.

2: Jarvela and Linstedt, Isoform-specific tethering links the Golgi ribbon to maintain compartmentalization, Mol. Biol. Cell (2014) 133-144.

3: Xiang et al., Regulation of protein glycosylation and sorting by the Golgi matrix protein GRASP55/65, Nat. Commun. (2013) 1659.

論文1では、ゴルジ層板形成における、GRASP55/65、 GM130、Golgin45のそれぞれの寄与の程度が明らかにされ た。 siRNAによる単一のGRASPのノックダウンの場合、囊 の最大管腔幅は、コントロールに比べて約 1.2 倍に増加し、 両方のGRASPの二重ノックダウンの場合には、約 2.6 倍に 増加することが定量電子顕微鏡法によって示された。単一 GRASPおよび二重ノックダウンによって、扁平なゴルジ囊 の形状は乱れたが、これまでの他の研究報告と異なり、層板 構造は分解しなかった。またGRASP55/65の二重ノックダウ ン細胞に GRASP55、GRASP65、GM130、Golgin45のいずれ かを過剩に発現させると、囊の形状は、単一GRASP ノック ダウンの時と同程度までに回復した。ただし、GM130を発 現させた場合、他の3つを発現させた場合と比べると回復の 程度が低かった。これらの結果は、囊の形状が可逆的に変化 し、GRASP55/65 と Golgin45 はゴルジ層板形成において相補 的に機能することを示唆する。

論文2は、Killer Red（KR）によるGRASPの急性的不活 化を用い、ゴルジスタックの横方向のつながり、つまりリボ ン形成におけるGRASP55/65の寄与を検証した。KRタグ付 けしたタンパク質は、波長 $561 \mathrm{~nm}$ の光を照射すると、それ 
In article 2, Jarvela and Linstedt used acute inactivation with Killer Red (KR) to study the involvement of GRASPs in the linkage between Golgi stacks and in Golgi ribbon formation. KRtagged proteins can be inactivated by irradiation with 561-nm light, because this results in the production of reactive oxygen species that can denature proteins. In fluorescence recovery after photobleaching (FRAP) analysis, in which cis- and trans-Golgi marker proteins were fused to GFP, the fluorescence of the cis-Golgi region was not recovered in the GRASP65-inactivated cells, but it was rapidly recovered in GRASP55-inactivated cells. Five minutes after GRASP65 inactivation, the fluorescence recovery of the trans-Golgi region was reduced. These results indicate that disruption of the cis-cisternae influences the medial- and trans-cisternae gradually; this is consistent with the results obtained for the cisternal maturation model. Redistribution of "single-GRASP" into the entire Golgi maintained the ribbon structures, but it also induced the loss of Golgi compartmentalization and impaired glycosylation of cell surface proteins. Impairment of glycosylation in treated Golgi was evidenced by the fact that GS-II lectin labeling in these proteins was higher by more than 2-fold as compared to the control. GS-II lectin recognizes terminal $N$-acetyl-D-glucosamine residues in glycosylation intermediates, and an increase in GSII labeling on the cell surface indicates a decrease in later stages of glycosylation. The authors suggest that impaired glycosylation may be caused by the loss of Golgi compartmentalization, where Golgi enzymes become mixed because of the fusing together of cis-, medial-, and trans-cisternae.

In article 3, Xiang et al. examined functional changes of the Golgi in GRASP-depleted cells. Both single and double knockdowns increased the transport of $\alpha 5$ integrin and vesicular stomatitis virus glycoprotein (VSV-G), as demonstrated by radioactive pulse-chase labeling, EndoH digestion, flow cytometry, and electron microscopy. Data showed that GRASP knockdown increases membrane binding of COPI- and COPII-coat components and the average number of vesicles adjacent to a Golgi stack. This evidence supports the author's hypothesis that disruption to the Golgi stack caused by double knockdown of GRASP increases the transport vesicles' accessibility to the Golgi, and that this results in increased trafficking. Further, the results of lectin binding assays and mass-spectrometry demonstrated that high-mannose-type and complex-type glycans are reduced in double GRASP-depleted cells by one-third and one-sixth, respectively. GRASP knockdowns had no effect on general protein expression levels. Thus, the authors speculated that the structural changes in sugar chains observed in knockdown treatments were the consequence of rapid cargo movement through the Golgi, which limited enzymatic reactions.

GRASP55/65 act as factors for vertical Golgi stacking [Barr
によって生じる活性酸素種により不活化する。シスやトラ ンスのマーカータンパク質とGFPの融合タンパク質の光褪 色後蛍光回復（FRAP）解析によって、GRASP65を不活化し たゴルジでは、シスゴルジの蛍光が回復しないのに対して、 GRASP55を不活化すると、迅速に回復することが示された。 またこの際、GRASP65の不活化を行ってから 5 分ほど経つ と、トランスゴルジの蛍光が、コントロールと比べて減少し た。これは、GRASP65の不活化により起こったシスゴルジ 崩壊の影響が、時間とともに中間やトランスゴルジに広がる こと、つまり層板成熟が起こったことを示唆する。また、単 一GRASPをゴルジ体全体に発現させた場合、ゴルジリボン は維持されたが、シス・中間・トランスのコンパートメント が消失し、細胞表面へ輸送されるタンパク質への糖鎖付加が 部分的に阻害された。この阻害は、GS-IIレクチン標識の増 加によって確認された。GS-IIレクチンは、糖鎖末端に露出 したN-アセチル-D-グルコサミン、つまり糖鎖付加における 中間生成物を認識する。このため、上述の GS-II レクチン標 識の 2 倍程度の増加は、後期糖鎖付加反応が阻害されたこと を示唆する。これらの結果は、一部のシス・中間・トランス 囊の融合、つまりゴルジコンパートメントの消失によりゴル ジ体内の様々なタンパク質が混合し、不完全な糖鎖が増加し たことを示唆する。

論文3では、GRASP55/65あるいはいずれかのノックダ ウンを行い、それぞれの場合におけるゴルジ体の機能的変化 が調ベられた。放射性パルスチェイス標識・EndoH消化・フ ローサイトメトリー・電子顕微鏡などの様々な技術によっ て、細胞表面タンパク質である $\alpha 5$ インテグリンと VSV-G (vesicular stomatitis virus glycoprotein) の輸送が、単一の GRASPおよびGRASPの二重ノックダウンにより増加するこ とが示された。著者らは、この輸送の増加は、二重ノックダ ウンに伴う層板構造の崩壊によって、輸送小胞がゴルジ体の より広い範囲にアクセスできるようになったためであるとい う仮説を立てた。この仮説を支持するデータとして挙げられ るのは以下の2点である。GRASP55/65のノックダウンによ り、COPIおよびCOPII被覆タンパク質と膜の結合が高まっ たこと、また、一つのゴルジ層板に隣接する小胞の数が増加 したことである。レクチン結合試験と多段階質量分析法によ り、二重ノックダウンでは、タンパク質あたり、高マンノー ス型糖鎖数がコントロールに対して $1 / 3$ 程度に、複合型糖鎖 数が $1 / 6$ 程度まで減少することが示された。また、これらの 細胞では、小さな遊離の糖鎖が増加していた。GRASPノッ クダウンは、タンパク質の発現レベルには影響を及ぼさない ため、これらの糖鎖構造の変化は、タンパク質がゴルジ体を 通常より速く通過し、糖鎖修飾酵素が十分に作用できなかっ たためであることが示唆された。

これまでに、GRASP55/65は、縦方向の層板形成因子と して働くことが示されている［Barr et al., 1997; Shorter et al., 
et al., 1997; Shorter et al., 1999]. Article 1 [Lee et al., 2014] showed that GRASP55/65 are complementary to Golgin45 in the function of stack formation. Stack formation is thought to limit the accessibility of vesicles and slow down protein transport through the Golgi. Indeed, article 3 [Xiang et al., 2014] showed that the slow movement of proteins within the Golgi provides sufficient time for glycosylation and sorting. In addition, article 2 [Jarvela and Linstedt 2014] showed that GRASP55/65 are involved in the compartmentalization of cis-, medial-, and trans-cisternae within the Golgi. It should be noted that articles 1 and 3 report inconsistent results regarding Golgi stacking. In particular, article 1 suggests that double knockdown of GRASP55/65 does not disrupt stacking, while, in article 3 , the authors interpret their data in the context of their previous work and conclude that double knockdown disrupts stacking. It is important to determine whether the increased protein transport described in article 3 was caused by increased accessibility, increased surface area made available to the vesicle budding machineries by cisternal unstacking, or disruption of cisternal flatness as described in article 1. To address this question, it would be necessary to investigate, in detail, the stack structure under identical siRNA-treatment conditions.

Reported by Ayano Satoh ${ }^{1}$, Youko Hasegawa ${ }^{2}$ and Yasuko Honjo ${ }^{3}$ The Graduate School of Natural Science and Technology ${ }^{1}$, Faculty of Engineering ${ }^{2}$, Okayama University, Okayama, Japan

E-mail: ayano113@cc.okayama-u.ac.jp

FAX: +81-86-251-8021

Research Institute of Radiation Biology and Medicine ${ }^{3}$,

Hiroshima University, Hiroshima, Japan
1999]。論文1では、GRASP55/65 は、Golgin45 と相補的に縦 方向の層板形成に寄与することが示された。通常、層板形成 により小胞のアクセスが制限され、ゴルジ体内のタンパク 質の輸送が遅くなると考えられている。実際論文3では、層 板形成により、タンパク質のゴルジ体をゆっくりと通過す るため、十分な時間をかけた適切な糖鎖付加と分類が行わ れる可能性が示唆された。またこれに加えて、論文2では、 GRASP65 はシス、GRASP55 は中間、トランスのコンパート メントの維持に寄与することが示された。特記すべきは、論 文 1 と 3 には、層板構造に関した 1 つ矛盾点があることで ある。論文 1 では、GRASP55/65の二重ノックダウンの場合、 縦方向の層板分解は起こらなかった。一方、論文3では、著 者らの以前の研究結果である、二重ノックダウンにより層板 構造が分解する、という前提で実験結果が解釈されている。 論文3ではさらに、この層板構造の分解に起因して、タンパ ク質の輸送が増加することが示された。論文 1 で層板分解が 起こらないことを鑑みると、ノックダウンによりタンパク質 輸送が増加したのは、ゴルジ震の形状の乱れによってその表 面積が増加し、小胞が通常よりもアクセスしやすくなったた めであるとも考えられる。この論文 1 と 3 の層板構造の違い を検証するため、同じsiRNA処理条件下における層板構造の 厳密な再調査が望まれる。

佐藤あやの

岡山大学大学院自然科学研究科

長谷川容子

岡山大学工学部生物機能工学科

本庶仁子

広島大学原爆放射線医科学研究所 